\title{
THE LEARNING MODEL IMPLEMENTATION OF SASAK, BALI-LOMBOK AND BUGIS ETHNICITY MULTIGENIC- HOMOGENIC LOCAL TRADITION-BASED CIVICS LITERACY IN MATARAM CITY ELEMENTARY SCHOOL LOMBOK WEST NUSATENGGARA
}

\author{
By \\ Solihin Ichas Hamid ${ }^{1}$, Tuti Istianti ${ }^{2}$, Baiq Zohri Uyni ${ }^{3}$, Ni Nyoman Elly Setiawati ${ }^{4}$, \\ G. Ayu Ariyanthi ${ }^{5}$ \\ ${ }^{1,2}$ Lecturers at Indonesia University of Education in Bandung \\ ${ }^{3}$ KSDN 7 Selaparang, \\ 4,5SDN 1 Cakranegara Mataram Lombok NTB \\ Email:
}

\begin{tabular}{l}
\hline Article Info \\
\hline Article history: \\
Received July 9, 2021 \\
Revised August 20, 2021 \\
Accepted Sept 11, 2021 \\
\\
\hline Keywords: \\
Antioxidant, Meniran, Tea \\
Functional Drink
\end{tabular}

Corresponding Author:

\begin{abstract}
The implementation of collaboration with teachers in SDN Selaprang 7 and Cakranegara 1 Mataram City Lombok NTB was conducted corresponding to health protocol during the pandemic situation, that is, the by the dual system, both using technological information devices teachers visit program to student's group. Apart from the situational limitation, the ethnic-pedagogic approach in this research delivers a visible outcome target, at least in the behavior changes and teachers' understanding of the demand of multidimensional Literacy development, which is a part of the curriculum message content for building student's character since elementary school. Exploring the local wisdom value contained in a variety of traditional arts such as verbal expressions, audial chants, visual appearances, and combinations of games and exhibitions, either virtual or directly, has the potential to become a medium is the message in cultural literacy and citizenship development. Traces marks and learning outcomes of citizenship literacy models based on homogeneous and multigenic local wisdom in elementary schools of Mataram City, Lombok, NTB found in this study are : 1) teachers' involved research collaboration for developing Civics Literacy in elementary school can make integral revitalization of their professional task demand to encourage the process and learning outcome of the students' entirely conforming to the elementary school students' requirements; 2) Covid-19 pandemic situation, aside as an obstacle for achieving learning standard, remain gives the opportunity to develop technological networkbased learning alternative with its all practical innovation and combination in the field; 3) the implementation of Civics Literacy development becomes pleasant refreshment medium for student from monotone situation as a result of partial academic assignments because it integrates learning activities in which it will more explore students' potential in absorbing and internalizing cultural values instilled within family and community both homogeneously and multi-culturally.
\end{abstract}

This is an open access article under the CC BY-SA license.

\begin{tabular}{ll} 
& This is an open access article under the CC BY-SA license. \\
\hline Corresponding Author: &
\end{tabular}




\section{INTRODUCTION}

Sasak ethnic community, with its cultural figure and traditional culture, has been known as native people in Lombok West Nusatenggara. According to their history, the Sasak tribe in Lombok once become part of the Bali Kingdom's glory because its relic of past time is still apparent and discoverable, such as Karawitan art performance as the Sasak traditional dance musical accompaniment is really similar to Balinese Karawitan Gending. However, Sasak people indeed have their songs and language, different from Balinese songs and language. Even though Balinese language song is influential to Sasak people's language expression, aside from the proximity factor, Bali presents rapid progress, particularly in the tourism sector in the country. Other than that, the Balinese had a substantial influence on the Sasak people in Lombok Island; many Balinese had indigenous norms. However, they still claimed themselves as Lombok people, so that the acronym of Balok (Balinese-Lombok) is widely known today. Such strong influence of Balinese culture in Lombok island to this day, even though generally Sasak tribe development has become part of the Islam kingdom, that is why Lombok island is known as "a thousand masque" city, with numerous Santri in the island. With this description, the current Sasak people's life and tradition, or even since the past kingdom era, have changed into Kingdom. Commonly, Sasak people are Muslim. However, as an Indonesian ethnicity of the Sasak tribe, they are still friendly to other ethnicities. As obedience Muslims in Mataram city particularly and Lombok island in general, during the historical records of the past, no significant conflicts were based on ethnic and religious differences, even if later it was revealed that there were frictions and disputes between social groups in Mataram city(2020). The cause of the problem is economic problems and partial issues of political extremism that did not represent the whole community - a common problem in many places of the country.

With the society development dynamic occurred, in which people mobility and heterogeneity keep on growing, as the indigenous ethnic, Sasak people still can live side by side in safe, harmony, and peaceful with other ethnicities as the settlers Nusatenggara. With that demographic map, the existence of ethnic diversity has enriched Mataram city citizens in Lombok island - at least with them who came from the nearest Island and other Island such as in Java or even South Sulawesi. Hence, culturally, Sasak people have known and are aware to accept acculturation with other ethnicities in the country. Therefore, from the past until today, Sasak people had shown their presence as ethnicities with a unique cultural and lingual identity. Furthermore, it is maintained into a coexistence of local sub-cultures that persist along with regional development from time to time. Thus, along with national development, and the implementation of education, especially the Sasak sub-culture, it is no doubt that they contributed to the cultural diversity of the archipelago and the implementation of the Diversity of the Sasak Gumi itself.

Therefore, related to the educational effort in strengthening nationality and Civics spirit, which will become the foundation in developing future generation character development, it is necessary to develop by strengthening local wisdom value which becomes every region's development. The passion for building understanding and awareness has been described in the regional development map and its derivatives of the curriculum program in school. Therefore, developing a model of local tradition-based Civics literacy through curriculum implementation in the school was intended to become a strategic step to prepare youth generation and building character as a good citizen, not only as a scientific insight which will become a basic reference but the social and moral integration obtained through instilling cultural attitude developed since school age.

\section{A. The focus of the Problem and Objective of the Study}

The focus of the study and Objective of the study is formulated into the following questions

1. How is the design of the Learning Model in Sasak, Bali-Lombok, and Bugis Homogenic-multigenic ethnic Local Wisdom-Based Civics Literacy in Mataram City Elementary School Lombok NTB?

2. How is the model implementation of Sasak, Bali-Lombok, and Bugis homogenic-multigenic ethnic Local Wisdom-Based Civics Literacy through Elementary School Civics learning in Mataram City Lombok NTB?

As for the Objective of the Study, are

1. Developing conceptual design model of Sasak, Bali-Lombok, and Bugis Homogen-multigenic ethnic Local Wisdom-Based Civics Literacy during Pandemic in Mataram City Elementary School Lombok NTB.

2. Developing the praxis model implementation of Sasak, Bali-Lombok, and Bugis Homogen-multigenic ethnic Local Wisdom-Based Civics Literacy through Elementary School Civics Learning during Pandemic in Mataram City Lombok NTB.

\section{B. Literature Review}

Developing Model of Sasak, Bali-Lombok, and Bugis ethnicity homogenic-multigenic Local WisdomBased Civics Literacy in Mataram City Lombok West Nusatenggara

1. Sasak Ethnicity and Local Wisdom Description in Lombok West Nusatenggara

Sasak people are one of the ethical groups who lived and settled in Lombok Island West Nusatenggara. Strong evidence was spread across the island marked with the development of the unity/kedatuan system, which is the origin 
International Journal of Social Science (IJSS)

Vol.1 No.3 October 2021, pp: 137-144

ISSN: ISSN: 2798-3463 (Printed) | 2798-4079 (Online)

DOI: $\underline{\text { https://doi.org/10.53625/ijss.v1i3.405 }}$

of the civilization and culture in language similarity that later known as Sasak language. Other tribes in the Sumbawa and Bali island, even though they indicate the same lingual root, do not include the Sasak tribe because they express their uniqueness as ethnic unity, Sumbawa, Dompu, and Mojo tribes.

The name of Sasak itself comes from sak sak, which means Sampan, in the oral tradition, it often refers to 'one'. It makes sense if there is any who consider that the name of Sasak was from sak sak, the sound of cloth spinner sound which pulls string hit repeatedly because one of the Sasak popular traditions is their woman crafts in weaving cloth. The historical source is the inscription found in 11 century reveal that Sasak meaning refers to its human group as ethnical unity, was cannot be separated from the meaning of 'Lombok' which become the name where they live, as revealed in Lombok Sasak Mirah Adhi, as mentioned in 'Kakawin Negara Kertagama' by Mpu Prapanca during Majapahit era. In Kawi language, the word 'Lombok' means straight or honest, 'Mirah' means jewel, 'sasak' means reality, and ' $a d i$ ' means promising or the foremost. Hence, Lombok Mirah Sasak Adi stresses honesty as the jewel of a good reality.

The geographical map of West Nusatenggara, as one of the provinces, is consisted of 2 large islands, that Lombok and Sumbawa. Lombok island is settled by the Sasak tribe, while in Sumbawa island, there are 3 other ethnicities, Dompu, Bima, and Mboju. Lombok island most of the residents is Sasak people which in administration was divided into 4 regions, i.g., Mataram City, West Lombok, North Lombok, and East Lombok. Sasak people as the majority population were around 3 million people, in which about 2.5 million of them mostly live in Lombok island. The official data in 2001 shows that the population in NTB is 2,722,123 people. It means that there are other ethnic, aside from Balinese, live in Lombok Island, but they are not like Sasak people. It occurs because of several factors such as trading relationships, religious missionaries, education, government assignment, and other business that always takes place. Therefore, as occurred in other regions, Sasak people with their culture and civilization has their historical development, since the entering of Hindu-Budha belief, colonialism, and Islam.

Today, most Sasak people are Muslim, but we still can find traces of the old beliefs. It occurs since the coming of the Islam civilization in Lombok Island, precisely in North Lombok. The relic can be found in the Bayan culture with the Wetu telu ritual concept, and also a small group from the royal family who fled to the mountains and called the Boda group. Regarding preserving cultural heritage, Sasak people still preserve cultural tradition in the past, which did not come from religious teachings but as a tribute to their ancestors' legacy, and it is very useful as a conflict resolution model which often occurs in the past between the Sasak tribe themselves or with other ethnical settlers in Lombok island.

The cultural relic preserved until today was maintained and preserved as a Sasak cultural art, and local wisdom values preservation event is Perang Topat. By holding Perang Topat, traditionally Sasak people will be revived to explore and re-actualize their ancestors' legacy values, and seeing the life, Sasak people should get along with their fellow Sasak, or other ethnic in Lombok island such as Bali, Java, Bugis, et cetera. Hence, during the Perang Topat ceremony, it was also created cooperation between ethnicities, regardless of religion and belief among the people in Lombok island, particularly between groups who realize that they are bound to be different. So that war to defeat each other was not a beneficial option. However, it is a sublime awareness of differences and diversities in life among humans that is a reality and the will of God the Mighty Creator. Hence, initially for Sasak people, if Perang Topat was a way to solve conflict for a unity egoism disputes among fellow Sasak people themselves.

The dynamic development when the conflict potential was getting widely open occurred with another group besides Sasak ethnic. The resolution model of traditional conflict owned by the Sasak and its social context develops into tradition involving inter-ethnic or ethnic-cultural spirits with a different belief. As in Sasak and Bali ethnicity, or among Sasak people who have different faiths, ways of life, and customs.

Besides festivities revealed in the local show tradition of Perang Topat event, solemn philosophical values and local wisdom stored in cultural sheath existed in Sasak saying gain its place and time introduced to public which most likely they did not familiar anymore of the latest advancement and unstoppable global development excess. Some communal local wisdom values described in verbal saying, literature, folklore, anthem, and games as the medium the articulation to ceremony still live and maintained signifies Sasak culture richness, the following is the description:

Table 1. Classification of local Traditional Cultural Art Diversity Storing Local Wisdom of Sasak People Ethnicity

\begin{tabular}{|c|c|c|c|l|}
\hline No & Form & Characteristics & Content & \multicolumn{1}{c|}{ Sampling } \\
\hline 1 & Literature & Verbal Utterances & 'proverbs & $\begin{array}{l}\text { Saling ajinang, Tertip-terpi, Tegug, } \\
\text { Solah Parateg, Soloh, Tetes,Saling } \\
\text { saduq Besemeton, Ra'i, bedadayan }\end{array}$ \\
\hline
\end{tabular}

Journal homepage: https://bajangjournal.com/index.php/IJSS 


\begin{tabular}{|c|l|l|l|l|}
\hline 2 & Tale & $\begin{array}{l}\text { Oral, written } \\
\text { Narration }\end{array}$ & Folklore & Putri Mandalika \\
\hline 3 & Song & Oral, vocal & Song & Barugaq Elen, Gurur Mayang \\
\hline 4 & Dances & $\begin{array}{l}\text { Rhythmical } \\
\text { harmonic } \\
\text { movement }\end{array}$ & $\begin{array}{l}\text { Heroic } \\
\text { Mutual } \\
\text { cooperation }\end{array}$ & $\begin{array}{l}\text { Tari Tandang mendet } \\
\text { Tari tandak Gerok }\end{array}$ \\
\hline 5 & Games & Free movement & Child Education & Budokan \\
\hline
\end{tabular}

\section{Conceptual design of Civics Literacy Development in Implementing Sasak Local Wisdom-Based School Curriculum in Lombok NTB}

Conceptually, design in developing local wisdom-based Civics literacy can be constructed in two models, that are 1), Homogenic model and 2) Multigenic model. The construct of homogenic model development is based on the homogenic reality, which became a reference in observing cultural roots in every region as national cultural identity, source, and diversity image authentically. The implementation of the homogenic model can be conducted both in their cultural origin and preserved by its supporter from outside in a place that became a migration area of various Archipelago ethnicity. The preservation of similar cultural traditions by the supporting community indicates the existence of a healthy multi-cultural strength because each supporter of the conventional system and cultural tradition forms an attitude of mutual respect for the reality of the differences that characterize their existence.

a. Designing Homogenic Model Design

Homogenic model, the term Hamid Hamid, S. Ichas (2021) proposed, is an approach to implement Civics Literacy learning developed based on similar local traditions as the learning social-cultural environment. For example, as conducted in learning implementation in Lombok West Nusatenggara, Sasak's ethnic dominant environment meets the historical facts called the indigenous native with their largest population in Lombok Island NTB. Moreover, it might also be other ethnic groups being the majority in their limited environment, such as the Balinese ethnicity in Lombok, known as the Balok, because the Balinese existence in Lombok has a long history as second natives well as the Bugis and Javanese and other tribes. As long as their existence and togetherness are under the same domicile environment, they can show an identity marking their self-image. The development of Civics literacy based on homogeneous local traditions of any ethnicity does not have to be the only option because it is located in the area from which they come, such as the Sasak people in Lombok, the Minangkabau people in West Sumatra, the Sundanese in West Java, et cetera. (Hamid, S Ichas: 2020)

The Homogenic model of conceptual design has the basic functionality as a medium is message to instill Civics moral values of local wisdom-based in their mother language which becomes historical house and cultural root of a people's identity origins. Although the later generation seems to lack support as their mother tongue richness legacy, their linguistic, social environment has shifted and changed by the new language development from outside. However, genetic identity in cultural and nationality context is a part of cultural, psychological reality worth to be saved. Every nation in the world also has arrived at the point of awareness that being part of the world does not necessarily lose its own culture, which comes from local cultural diversities richness (Hamid, S.Ichas, 2021). Therefore, through the implementation of homogenic local culture-based learning, students, even though losing their power and environment in preserving their mother tongue language, still can be expected again to build their sense of historical ownership and pride of identity richness which becomes one of the characteristics and holder od national cultural diversity.

Therefore, the urgency of homogenic functional model in building local wisdom-based Civics literacy through Civics learning as the central theme in developing school curriculum can be applied both in early stages of class and in the early age child education until elementary school education, either in rural areas schools which its cultural homogeneity is still substantial or in an open school environment for cross-influence and cultural dynamical changes of its people.

\section{b. Developing Multigenic Model Design}

Multigenic model as the second choice (Hamid, S.IchasL 2021) was developed based on the reality of mixing local culture richness amid the society which becoming a supportive environment where the educational institution lies. The mixed local culture richness has to turn into an environmental condition influential toward social, linguistic, and dynamical cultural politics of society. Hence, the multigenic model is a strategic option to implement the local tradition-based Civics literacy model in the Archipelago diversity context.

The conceptual design of the multigenic model has a strategic function in instilling moral values, local wisdombased Civics within diversity at one hand, and nationalism integration as historical legacy and the Objective of political independence. Hence, the mixed model directly becomes the double instrument in uplift local culture element as preserved within the local lingual utterance, but also becomes the unifier and binder of the national spirit togetherness 
International Journal of Social Science (IJSS)

Vol.1 No.3 October 2021, pp: 137-144

ISSN: ISSN: 2798-3463 (Printed) | 2798-4079 (Online)

DOI: https://doi.org/10.53625/ijss.v1i3.405

because, from the implementation of multi-ethnic learning, each student will enter the learning area to know the regional culture richness within a frame of awareness of diversity which belongs to the Almighty Creator, God Almighty, for the gift of diversity.

In its implementation, the multigenic approach model will be more praxis and easier because Civics morals are obtained from the local wisdom value of every region; at least, it could be two or three. Not only to explore traditional uniqueness, but it is more on language differences because in a language ethnicity differences show their marks, and no matter how hard, how complex each local language which stores the moral message, it will be easier and more beautiful to be expressed and listened through a song or hymn. Several regional songs in the archipelago with different languages have become popular songs of all time. Thus, the existence of regional songs that have been known in the community for almost all time becomes a medium, and the message ease the teachers to articulate the content of civic moral values concept contained in local language expressions, thereby reflecting the wisdom, beauty, and charm of each region's wealth. in diversity as a unifier of the nation,

\section{Result and Discussion Analysis}

1. Developing conceptual model of Sasak Ethnic, Bali-Lombok, and Bugis Homogenic-Multigenic Local Tradition-Based Civics Literacy during Pandemic in Mataram City Elementary School Lombok NTB.

The Conceptual model development of local tradition-based Civics literacy, both homogenic or multigenic, was conducted at Elementary School in Lombok West Nusatenggara, either in Mataram city downtown as the province central city or others. Sasak people are indigenous natives in Lombok Island NTB developed as a citizen's people to the rural area, present as an open community toward melting pot dynamics. It is not only seen today, since the beginning of the republic after the independence Proclamation, but far before the event, that is since the Archipelago Kingdom. Therefore, even though Lombok is a region marked as the cultural house of indigenous natives for Sasak people. Generally, Sasak people lived side-by-side a long time ago with other ethnicities such as Bali, Bugis, and Java. With the three ethnic elements tinting the Lombok people's lives in NTB, the cultural development of the Sasak people expanded along with the inclusion of cultural and traditional influences that were then born expressing a mixture of ethnic elements such as Balinese in the Kindom period and Bugis in Islamic times. Therefore, culturally and politically, the Perang Topat tradition has been adopted by the elders of the Lombok community as a model for conflict resolution over the differences between the Sasak people themselves, including to other ethnic groups who have initially been immigrants in Lombok, NTB.

Perang Topat as a cultural ritual that becomes tradition, with its all accessories, has become a social-cultural kind of performance art. Therefore, every Lombok citizen, whether Sasak people or other ethnic knows the tradition because the content is actually a war of food for peace so that different Sasak people can respect each other as well as other ethnic groups such as Balinese and Bugis who have been living as the part of the indigenous community on Lombok island, NTB. As an original cultural tradition of the Sasak people, and able to involve other ethnic groups in the Lombok community, the Perang Topat can be a stimulus medium for the Homogenic Sasak model because it is expressed in the language and literature of the Sasak region, other ethnic groups such as Balinese in Lombok and Bugis present traditions brought from the homeland in their own language. Therefore, the Multigenic approach is the medium to facilitate local wisdom-based Civics Literacy development within the framework of diversity.

2. The Praxis Model Implementation of Sasak Ethnicity, Bali-Lombok, and Bugis HomogenicMultigenic Local Tradition-Based Civics Literacy through Elementary School Civics learning during Pandemic in Mataram City, Lombok NTB

The implementation of local wisdom values practices through Civics learning as the central theme in grade IV of SDN Selaparang and SDN Cakranegara 1 Mataram City Lombok, by carrying stimulus media such as games and performance of culture ritual event, was conducted through virtual technology due to Large Scale Social Restriction (PSBB), indeed displaying markable success, at least qualitatively seen from the active learning indicators for students' participation and teachers' creativity amid the boredom and saturation on Covid-19 Pandemic situation. Nevertheless, the pandemic has become a burden. The educational and learning process must remain in progress, likewise to other activities related to maintaining and increasing performance outcome of teachers' activity as the curriculum executor, the demand of achievement outcome of students' study both through online and limited offline. The model implementation of local traditional-based learning model related to the output of Civics culture literacy and other subject gain refreshments because the function of the medium is message in carrying lesson material comes from games actualization. Local culture art performance can enliven and present learning material and resources that existed and as the local heritage legacy which must be preserved and maintained. 
Games content such as Bledokan and cultural ritual shows such as Perang Topat exist among the Sasak people, the present generation kids. Even if they are not in a pandemic situation, they are no longer know the game because it does not become their daily game anymore. Likewise, traditional art shows, even if it can be seen directly on the crowd in an off-pandemic Covid-19 situation, but still, it did not directly understand by many kids today in which they did not sufficiently understand and fluent in grasping the local language. Therefore, to insert it within curriculum process at school related to the implementation of tradition-based Civics Literacy by the teacher become a strategic opportunity to introduce local culture richness to children in a language utterance which not of their era, articulating the content of functional social values in it such as the spirit of cooperation, mutual respect, tolerance, allowing each other to play, achieving mutual pleasure which is shown in audio-visual games and shows will be interesting to do in practice playing at school if the pandemic is over. At the same time, literary expressions existed in the chanting of ceremonial songs. The expressions of proverbial parental rhymes can be exciting sources and learning materials to be investigated by students and teachers in limited online and offline classroom interactions at school.

\section{CONCLUSION}

Based on the discussion result of this research, it can be drawn research conclusion and recommendation as follows:

1. The implementation of a learning model for local wisdom-based Civics literacy, either homogenous or multigenic, can become a strategic approach in developing attitude as in knowledge and cultural skill which becoming the sign of richness and pride of local identity from which they came from and were becoming a part of the integration of its social development.

2. The conceptual model of local tradition-based Civics literacy developed in SDN Selaparang 7 and Cakranegara 1 Mataram City can be applied both in Sasak Homogenic and Multigenic related to other ethnic existence, such as Bali-Lombok, Bugis, and others that becoming an integral part of Lombok NTB society since the last time, through dual system namely, online and limited online corresponding to Covid19 Pandemic situation.

3. The model implementation of Homogenic and Multigenic local tradition-based Civics literacy conducted in Civics learning by the teachers in SDN 7 Selaparang and SDN 1 Cakranegara Mataram City Lombok NTB has met the output both qualitatively and quantitatively based on teachers activity and creativity signifiers, and active participation and students' progress atmosphere amid limitation of Pandemic situation, through dual system application, namely, online and offline learning.

\section{Recommendation}

This research recommendation for further study mentioned as follows:

1. The implementation model of Homogenic local tradition in Civics literacy learning as a fundamental functional approach becomes the primary option in building cultural attitude strengthening, which will become the root of the entity and identity of students character in the middle of social-cultural dominant environment.

2. The Multigenic approach of the Archipelago diversity was recommended becoming the strategic option to build the fundamental attitude of nationalism culture through the implementation of Civics literacy.

3. The Homogenic-Multigenic approach partially sustainable in various conditions can become a dissemination package of diversity education through the Archipelago local tradition-based Civics literacy.

\section{REFERENCES}

[1] Duncker, K. (2015). Cultural citizenship: Understanding the natural states of freedom participation and equality in light of societies self-awareness, -contemplation, and -reflection through culture and cultural evolutionary learning by mode of media. Florence: European University Institute.

[2] Docherty, I., Goodlad, R., \& Paddison, R. (2001). Civic Culture, Community and Citizen Participation in Contrasting Neighbourhoods. Urban Studies, 38(12), 2225-2250

[3] Miller, T. (2002). Cultural Citizenship. In E. F. Isin, \& B. Turner, Handbook of Citizenship Studies (pp. 231 - 244). London: Sage Publications Ltd.

[4] Nila Riwut, Tjilik Riwut, Manajer Panatau Tatu Hiang

[5] Lee, T. (2013). Public Culture and Cultural Citizenship at the Thessaloniki International Film Festival. Cambridge, Massachusetts: Harvard University.

[6] Hamid, S. I., \& Istianti, T. (2018). Pengembangan pembelajaran PPKn di SD-MI. Bandung: UPI Kampus Cibiru.

[7] Hamid, S. I. (2015). Nilai Moral Kewarganegaraan Dalam Artefak Kehidupan Sosial Kultural Masyarakat Sunda: Studi Eksploratif Nilai Moral Kewarganegaraan dalam Ungkapan, Artikulasi Seni dan Ritual Adat Budaya Sunda. . Universitas Pendidikan Indonesia, Pendidikan Kewarganegaraan. Bandung: 
International Journal of Social Science (IJSS)

Vol.1 No.3 October 2021, pp: 137-144

ISSN: ISSN: 2798-3463 (Printed) | 2798-4079 (Online)

DOI: $\underline{\text { https://doi.org/10.53625/ijss.v1i3.405 }}$

[8] Hamid, S.I. (2015). Semiotika Pendidikan Kewarganegaraan dalam Tradisi Lokal Sunda. . Bandung: Rizqi Press.

[9] Hamid, S.I. (2016). A Description of Citizenship Moral Values in Sundanese Society. Man In India, 96(12), 51255141.

[10] Hamid, S.I, (2017), Pendidikan Kewarganegaraan dalam Semiotika Sunda, Bandung, Cetakan ke 2. Rizqi Press.

[11] Hamid, S.I, (2017) A. Description of Citizenship Moral Values In Sundanese Society, @ Serials Publications Ma In India, 96 (12): 5125 - 5141

[12] Hamid, S. Rochas, Istianti, Tuti \& Abdillah, Fauzi, Firmansyah, Ferri Hidayatullah; (2019): The Indonesian Proverb Of Peace: Educational Semiotics Analysis For Cultural Citizenship Literacy; Proceeding, four the ICERD International Conference on Education and Regional Development.

[13] Hamid, S.I; Istianti, Tuti \& Abdillah, Fauzi (2020): Cultural Citizenship Literacy Learning Model: The Acquaintanceship In An Homogeneous Society, International Journal of Psychosocial Rehabilitation, Vol. 24, Issue 08, 2020 ISSN: 1475-7192 Received: 27 March 2020 | Revised: 20 April 2020 | Accepted: 05 May 2020 9104

[14] Hamid, S.Ichas, Nurjannah, Siti Kania Nopitasari, Gilang Tresna., (2021) Matic Implications Of Sundanese Pupuh Song in Building Moral Values Toward Elementary School Students; International Journal Of Social Science, Vol. 1 Nomor 02 August 2021.

[15] Hamid, S.Ichas, Istianti Tuti, Ismail Helmi, Abdillah Fauzi, (2021) Diseminasi Tradisi Lokal Model HomogeniikMultygenik dalam Membangun Literasi Budaya Kewarganegaraan pada siswa Sekolah Dasar, (Proceding) Virtual Summer Program 2021 The Magnificent Of Indonesian Traditional Games September 2021. 
